\author{
Abstracta Iranica \\ Abstracta Iranica Revue bibliographique pour le domaine irano-aryen \\ Volume 40-41 | 2019 \\ Comptes rendus des publications de 2017-2018
}

\title{
Johannes Hackl, Joachim Oelsner. "Additions to the Late Achaemenid textual record, Part I: texts from Uruk"
}

\section{Astrid Nunn}

\section{(2) OpenEdition Journals}

Édition électronique

URL : http://journals.openedition.org/abstractairanica/48246

DOI : 10.4000/abstractairanica.48246

ISBN : 1961-960X

ISSN : 1961-960X

Éditeur :

CNRS (UMR 7528 Mondes iraniens et indiens), Éditions de l'IFRI

\section{Référence électronique}

Astrid Nunn, « Johannes Hackl, Joachim Oelsner. "Additions to the Late Achaemenid textual record,

Part I: texts from Uruk" », Abstracta Iranica [En ligne], Volume 40-41 | 2019, document 19, mis en ligne le 15 juillet 2019, consulté le 24 avril 2021. URL : http://journals.openedition.org/abstractairanica/ 48246 ; DOI : https://doi.org/10.4000/abstractairanica.48246

Ce document a été généré automatiquement le 24 avril 2021.

Tous droits réservés 


\title{
Johannes Hackl, Joachim Oelsner. "Additions to the Late Achaemenid textual record, Part I: texts from Uruk"
}

\author{
Astrid Nunn
}

\section{RÉFÉRENCE}

Johannes Hackl, Joachim Oelsner. "Additions to the Late Achaemenid textual record, Part I: texts from Uruk", Orientalia 86/1, 2017, p. 42-96

1 Les textes de la fin de l'époque achéménide sont rares en Babylonie du sud - moins de 60 textes d'Uruk et de Larsa sont publiés. En comparaison, environ 890 textes de la Babylonie centrale et 850 de la Babylonie septentrionale sont connus, auxquels il faut ajouter environ 1020 textes conservés à Berlin et non encore publiés. Les AA. se concentrent sur les textes d'Uruk et de Larsa et en font l'inventaire. Ceux-ci proviennent en partie du marché des antiquités, en partie des fouilles d'Uruk. Les tablettes achetées sur le marché sont réparties dans le monde entier (Yale, Londres, Philadelphia, Arizona), les autres sont conservées à Berlin et Baghdad. Certaines appartiennent à des archives que les AA. essaient de reconstituer. Les thèmes sont de nature économique. Outre les tablettes déjà publiées, les AA. décrivent, transcrivent et commentent dans cette contribution 10 tablettes non encore publiées. 


\section{AUTEURS}

\section{ASTRID NUNN}

Université de Munich 